\title{
Wood-rotting basidiomycetes of Svalbard (Norway)
}

\author{
TIMO KOSONEN and SEPPO HUHTINEN
}

KOSONEN, T. \& HUHTINEN, S. 2008: Wood-rotting basidiomycetes of Svalbard (Norway). - Karstenia 48: 21-28. Helsinki. ISSN 0453-3402.

\begin{abstract}
Svalbard comprises several islands in the northern part of the Arctic Ocean. No larger tree species grow on the islands, but driftwood and construction timber have accumulated on the islands during the last 200 years. A thorough inventory of lignicolous basidiomycetous species was carried out on the island of Spitsbergen in 2001. The number of species found was 24. Of these fourteen were collected for the first time in Svalbard. Altogether 115 specimens were identified to species level. Corticioid fungi were the largest group with 84 specimens of 12 species. Some of the species found are seldom collected and poorly known also elsewhere. Only a few of the species were found in all the investigated areas. Half of the species were found only once or twice. Some of the new findings represent prominent range extensions.
\end{abstract}

Key words: Aphyllophorales, Corticiaceae, Svalbard, Arctic, dispersation, timber, driftwood

Timo Kosonen, Herbarium, University of Turku, FI-20014 Turku, Finland; e-mail: tikoso@utu.fi

Seppo Huhtinen, Herbarium, University of Turku, FI-20014 Turku, Finland; e-mail: sephuh@utu.fi

\section{Introduction}

Svalbard comprises four islands situated in the Barents Sea between the $76^{\text {th }}$ and $81^{\text {st }}$ latitudes. The only inhabited island, and also the largest, is Spitsbergen $\left(38000 \mathrm{~km}^{2}\right)$, the three uninhabited islands are Nordaustlandet $\left(14500 \mathrm{~km}^{2}\right)$, Edgeøya $\left(5000 \mathrm{~km}^{2}\right)$ and Barentsøya $\left(1300 \mathrm{~km}^{2}\right)$. In spite of its northern location, the climate in Svalbard is relatively mild. Warm sea currents sustain a yearly growth period of six to ten weeks (Hisdal 1998). Svalbard is home to 170 vascular plants including such dwarf shrubs as Betula nana L., Salix polaris L. and S. reticulata L., but not a single larger tree-species. The last trees existed before the beginning of Quarternary Period approximately 3 M years ago (Hjelle 1993).

There are, however, two alternative routes for dead wood to end up on Svalbard. Driftwood is carried by sea currents mainly from the Atlantic and northern Russia. Especially near human settlements this wood, to some extent even today, is used as construction material or as a source of energy. During the active mining period in the first half of the $20^{\text {th }}$ century substantial amounts of timber were shipped to the islands (Arlov 1996). Construction wood, visible today in the Isfjorden area and near the settlement of $\mathrm{Ny}$ Ålesund, is mainly associated with abandoned buildings and mining remnants. The protection of these sites by a Norwegian National Heritage Act has hindered the recycling of valuable timber (Krohn 1999), thus offering a substrate for lignicolous fungi.

Reports on the fungus flora of Svalbard have mainly dealt with Agaricales (Gulden 1996, Gulden \& Torkelsen 1996). A comprehensive study of lignicolous fungi of Svalbard was lacking prior to this study. Some sporadic sightings had been made and some of them had found their way to different herbaria. Gulden and Torkelsen (1996) present a list of 12 aphyllophoralean spe- 
cies found from Svalbard. The primary aim of this study was to make an inventory of lignicolous basidiomycetous species in the area. Secondly, based on the retrieved data, the aim was to evaluate whether there are vital populations in Svalbard. The third aim was to find out the characteristics of the local fungus flora and to clarify how species have migrated to the islands.

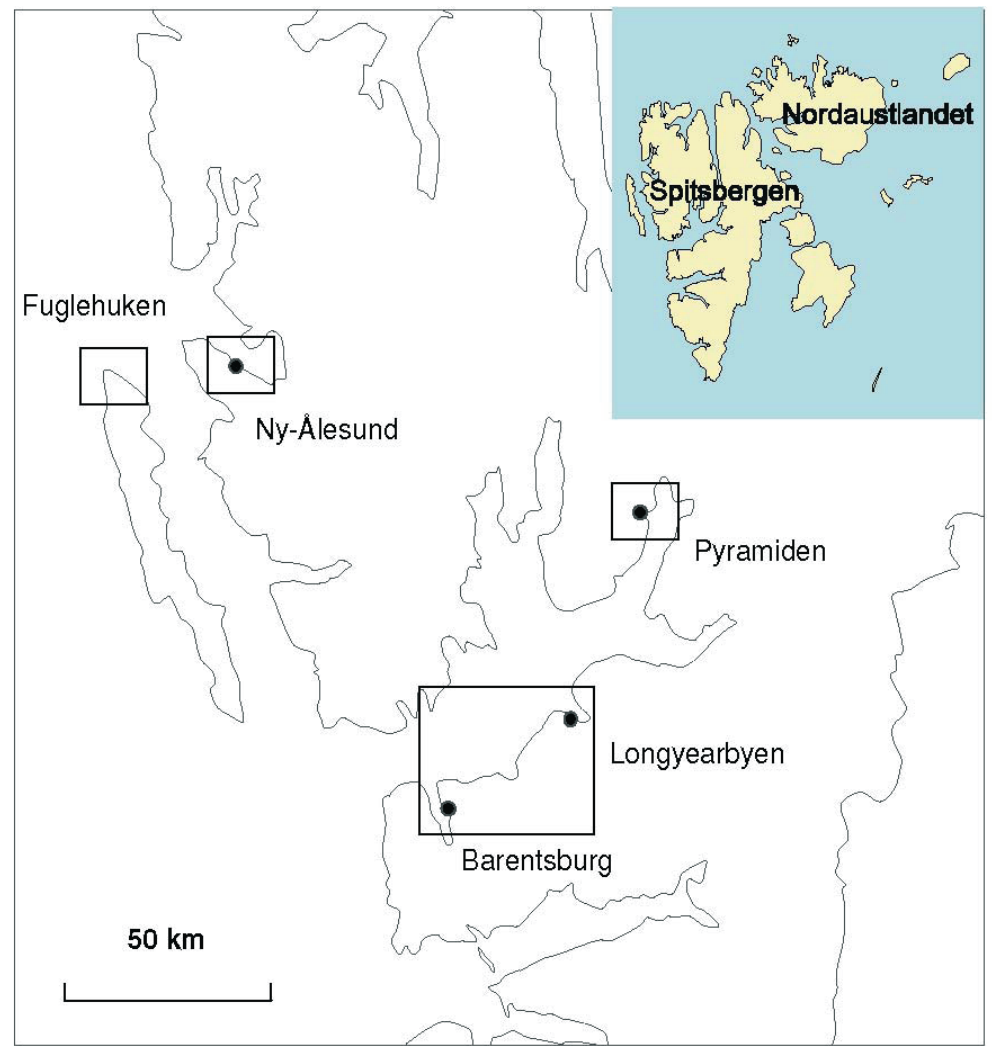

Figure 1. A close-up on Spitsbergen, the main island of Svalbard. Boxes refer to investigated areas.

\section{Materials \& methods}

The survey was carried out in four separate areas: NyÅlesund, Pyramiden, Fuglehuken and in the vicinity of Longyearbyen and Barentsburg (Fig. 1). These areas contain the major body of decaying woody material in central Spitsbergen as they have been central places of human activity (Hisdal 1998; Krohn 1999). The fieldwork took place between June $26^{\text {th }}$ and August $15^{\text {th }}$ in 2001. The number of wood fragments studied was approximately 13000 . The overall area covered in the survey was $0.25 \%$ of the land area (including glaciers) of Spitsbergen.

Ny-Ålesund is an old mining settlement where mining activity ceased after a fatal accident in 1962. Timber from the scaffoldings and destroyed constructions has spread over several square kilometres. The area surveyed here was ca 20 square kilometres. Fuglehuken is the northernmost tip of the island of Prins Karls Førland. Sea currents have carried several hundred relatively big logs onto the shores. This involved searching one and a half square kilometres. Pyramiden has been a Russian-run mining settlement from the beginning of the $20^{\text {th }}$ century. Mining activity ceased in 1999 and the settlement was deserted afterwards. Here six square kilometers were surveyed. On Nordenskiöldland the area between Longyearbyen and Barentsburg was surveyed. Surrounding Longyearbyen there are several closed mines. They have remained relatively intact during the past 50 years. Barentsburg is the last Russian-run settlement still inhabited. There is no road connecting Longyearbyen and Barentsburg, but on the shore strip between the two towns there are several smaller deserted settlements, telephone poles and experimental drilling stations resulting in numerous aggregates of decaying timber. The area covered was about 70 square kilometers. 
The material was studied with an Olympus BX40 research microscope using bright field optics. All measurements and critical observations were made using $\times 100$ Olympus UPlanFl objective. Drawings were made to a $\times 2500$ scale using a drawing tube. Spore sizes were measured from all collections except when there were more than ten fertile collections of a single species; then ten collections were chosen randomly. Where possible, 30 spores were measured from each specimen. All collections are deposited in TUR.
The names of the species follow Hansen and Knudsen (1997) except in Heterobasidiomycota, which are according to Jülich (1984). The host tree was identified using microscopical characteristics, described by Fagerstedt et al. (1996). Author abbreviations are according to Brummit and Powell (1992). The principal reagent used was Cotton Blue in lactic acid (CB). It was used both for drawing and measuring microscopical characters. The decay stage of the infected wood was determined by a method described by Renvall (1995).
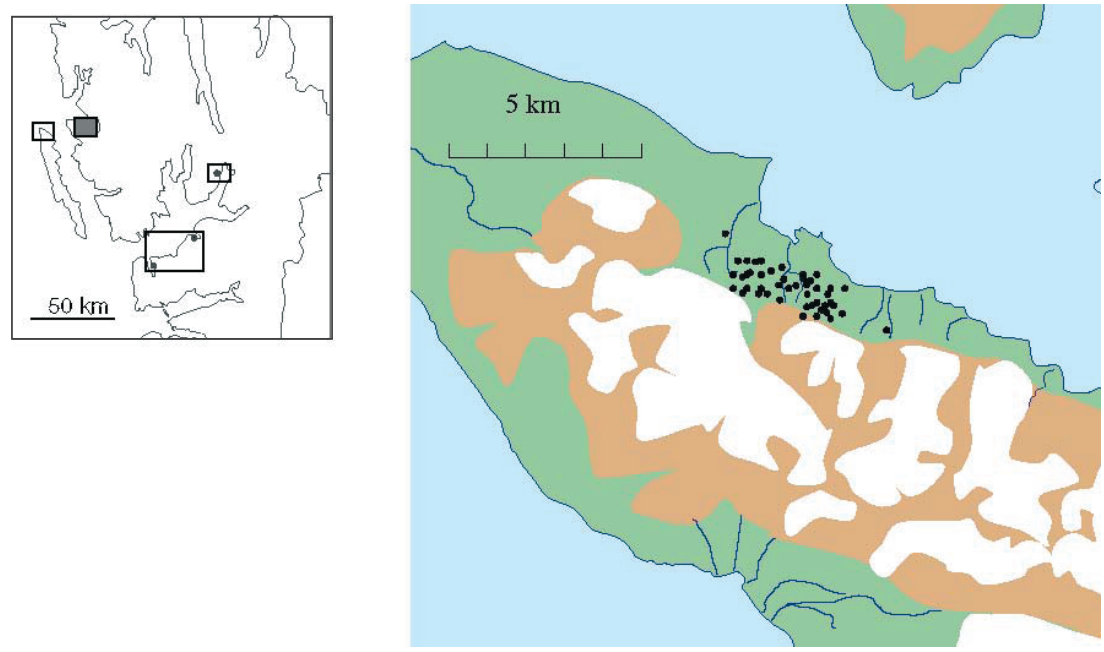

Fig. 2. Spatial distribution of observations, Ny-Ålesund.
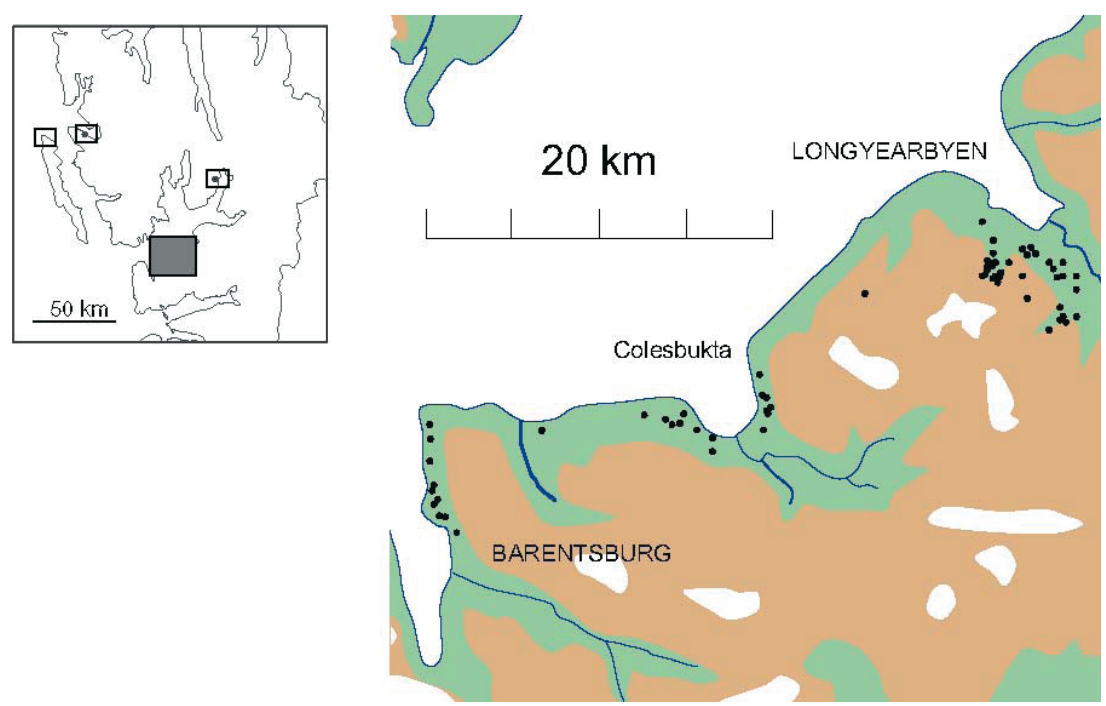

Fig. 3. Spatial distribution of observations, Nordenskiöldland. 


\section{Results}

Altogether 152 observations were made of basidiomycetous fungi growing on wood and 115 were identified to species level (Table 1.). Twenty four species were recorded: twelve were corticoid fungi, six were Heterobasidiomycetes, three were polypores, two were Gasteromycetes and one was an agaric. Fourteen of the species are new to Svalbard. Fungi were only found in two of the areas researched: Ny-Ålesund and Nordenskiöldland. Several hundred ocean carried logs were examined in Fugelhuken, but no fungi were found. In Pyramiden the amount of wooden pieces was low or practically non-existent compared to other settlements. No fungi were found. In Ny-Ålesund altogether 51 sightings of 13 species were made. The major body of the construction wood was within $1-2 \mathrm{~km}$ radius from the mines, as were also all the sightings (Fig. 2). In the area of Longyearbyen and Barentsburg altogether 64 sightings of 20 species were made. Three 'hot spots' can be defined: The abandoned mines around Longyearbyen, Colesbukta, and Barentsburg with its surrounding (Fig. 3).

Table 1. List of species found and the number of observations from spruce (Picea abies) and from pine (Pinus sylvestris). Species names in bold are new to Svalbard.

\begin{tabular}{|c|c|c|c|}
\hline Taxon & On Picea & On Pinus & Altogether \\
\hline \multicolumn{4}{|l|}{ TELIOMYCOTA } \\
\hline Achroomyces peniophorae & & 2 & 2 \\
\hline \multicolumn{4}{|l|}{ POLYPORES } \\
\hline Antrodia serialis & 14 & 1 & 15 \\
\hline Antrodia xantha & & 2 & 2 \\
\hline Gloeophyllum sepiarium & 3 & & 3 \\
\hline \multicolumn{4}{|l|}{ CORTICIOID FUNGI } \\
\hline Botryohypochnus isabellinus & 1 & & 1 \\
\hline Cylindrobasidium evolvens & 3 & 1 & 4 \\
\hline Dacryobolus sudans & & 10 & 10 \\
\hline Hyphoderma obtusum & & 1 & 1 \\
\hline Hyphoderma praetermissum & 6 & 4 & 10 \\
\hline Hypochniciellum molle & 5 & & 5 \\
\hline Peniophora incarnata & 6 & & 6 \\
\hline Peniophora pithya & 14 & 6 & 20 \\
\hline Stereum sanguinolentum & 1 & 7 & 8 \\
\hline Tomentella atramentaria & 1 & & 1 \\
\hline Tomentella subclavigera & & 1 & 1 \\
\hline Veluticeps abietina & 17 & & 17 \\
\hline \multicolumn{4}{|l|}{ GILLED FUNGI } \\
\hline Panellus mitis & 1 & & 1 \\
\hline \multicolumn{4}{|l|}{ HETEROBASIODIOMYCOTA } \\
\hline Dacrymyces capitatus & 1 & & 1 \\
\hline Dacrymyces microsporus & 1 & & 1 \\
\hline Ditiola radicata & & 3 & 3 \\
\hline Tulasnella bourdotii & 1 & & 1 \\
\hline Tulasnella violae & & 1 & 1 \\
\hline \multicolumn{4}{|l|}{ GASTEROMYCOTA } \\
\hline Crucibulum laeve & & 1 & 1 \\
\hline Nidularia deformis & & 1 & 1 \\
\hline Number of samples (altogether) & 76 & 39 & 115 \\
\hline
\end{tabular}


All the sightings grew on pine (Pinus sylvestris L.) or on spruce (Picea abies (L.) Karsten). Of the 106 wooden pieces in which superficial mycelium was observed, 69 (65\%) were spruce and $37(35 \%)$ were pine. Almost all the inhabited wood was still hard and the decay stage was between 1 and 2. Only four small logs, three of them infected by Antrodia serialis (Fr.) Donk and one by Ditiola radicata (Alb. \& Schwein. : Fr.) Fr., had decay stage between two and three. Over half $(59 \%)$ of the infected wood was located in unvegetated habitats (gravel, sand, coal etc). More than a third $(41 \%)$ of the infected pieces of construction wood were found from habitats with green vegetation. All the infected wood appeared to originate from abandoned and usually partly destroyed constructions. No fungi were found from driftwood. Excluding Barentsburg, the mining activity ceased in the investigated areas in the 1970s. As a result, the major body of the wood has lain on the ground for more than 20 but probably less than 50 years.

\section{Taxonomy}

Hyphoderma obtusum J.Erikss. - Fig. 4.

Hyphoderma obtusum is new to Svalbard. It was collected only once, from a small board made of Pinus. H. obtusum is extremely rare also elsewhere. There are less than ten herbarium collections from Scandinavia. H. obtusum from Svalbard fits well with the description by Eriksson and Ryvarden (1975) but has slightly larger spores than other collections of H. obtusum (Fig. $6)$. Some cystidia are also septate unlike the other H. obtusum specimens. Having only one collection, the taxonomic status of these differences is unresolved. There is another species close to $H$. obtusum, Hyphoderma lapponicum (Litsch.) Ryvarden, collected only once from northern Scandinavia. A study of the holotype showed that $H$. lapponicum has somewhat larger spores than the studied $H$. obtusum collections outside Svalbard, but smaller than the spores of $H$. obtusum from Svalbard. The spore size of the Svalbard collection is (7.9-) 8.2-11.1 (-11.9) $\times(5.3-)$ 5.5-7.0, $\mu \mathrm{m}$, mean $=9.5 \times 6.2 \mu \mathrm{m}, \mathrm{Q}=1.2-1.8$, mean $\mathrm{Q}$ $=1.5(\mathrm{n}=30$ spores, from 1 population $)$.
Hyphoderma praetermissum (P. Karst.) J. Erikss. \& Å. Strid - Fig. 5.

Ten Hyphoderma praetermissum collections were made and it can be considered as a rather common corticiaceous species in Svalbard. The basidiocarps are rather distinct and can be spotted quite easily as they grow also on the upper surface of their substrate. Because $H$. praetermissum has not been reported from Svalbard previously, it is probable that it is a relatively new species in the Svalbard mycoflora. The spore size of the material is 7.0-9.9 $(-12) \times(3.1-) 3.9-5.0(-5.2) \mu \mathrm{m}$, mean $=8.4 \times 3.4 \mu \mathrm{m}, \mathrm{Q}=1.4-2.5$, mean $\mathrm{Q}=2.0$ ( $\mathrm{n}=300$ spores, from 10 populations).

\section{Discussion}

The number of aphyllophoroid species known to exist in Svalbard was doubled (Table 1). The majority of the species found are generalists and relatively wide-spread in northern hemisphere (Torkelsen 1972; Eriksson \& Ryvarden 1975; Rayner \& Boddy 1988; Niemelä 2005). Many of them are typical pioneers (Renvall 1995). Rather surprisingly some poorly known and rather rarely collected species were also found, e.g. Dacrymyces microsporus P. Karst., Hyphoderma obtusum. and Tulasnella bourdotii Jülich. None of the 24 found species is red-listed in Scandinavia.

There is a rather clear distinction between abundant and rare species in Svalbard; twelve of the species were only found once; the five commonest species were found 10 to 20 times. The most "common" species were mainly polypores and corticioid species. The rare corticioid species in Svalbard are also rare in Scandinavia where their occurrence is relatively well known (Hansen \& Knudsen 1997; Kotiranta 2001). Together with present and previous observations, 26 lignicolous basidiomycetous species have been found from Svalbard. Approximately half of them have been found only once. There are indications that some species have found their way to the islands during the past 20 to 30 years, for example the previously unreported, conspicuous $H$. praetermissum, now found from ten localities. 


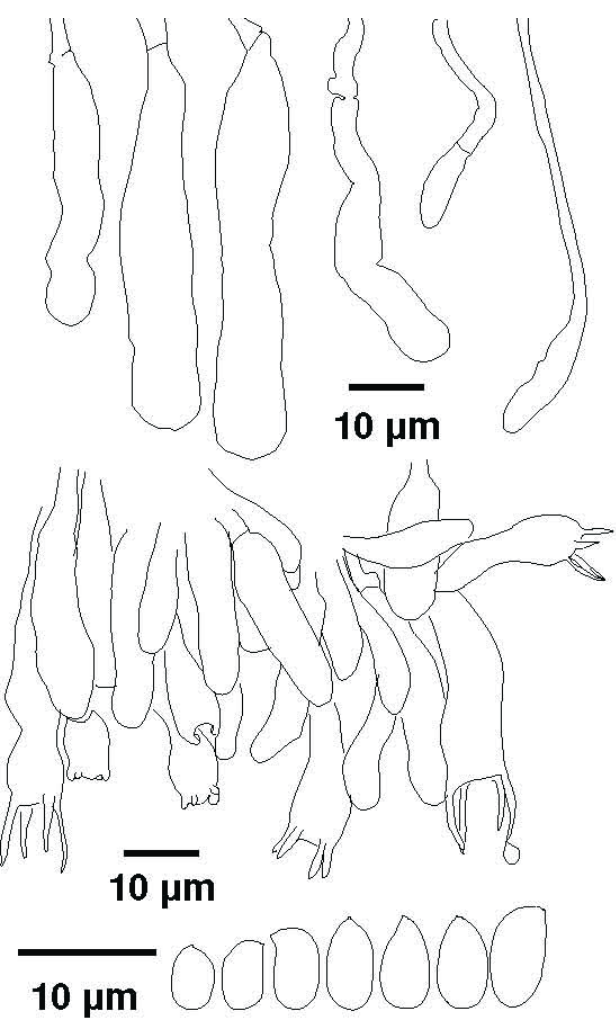

Fig. 4. Hyphoderma obtusum.

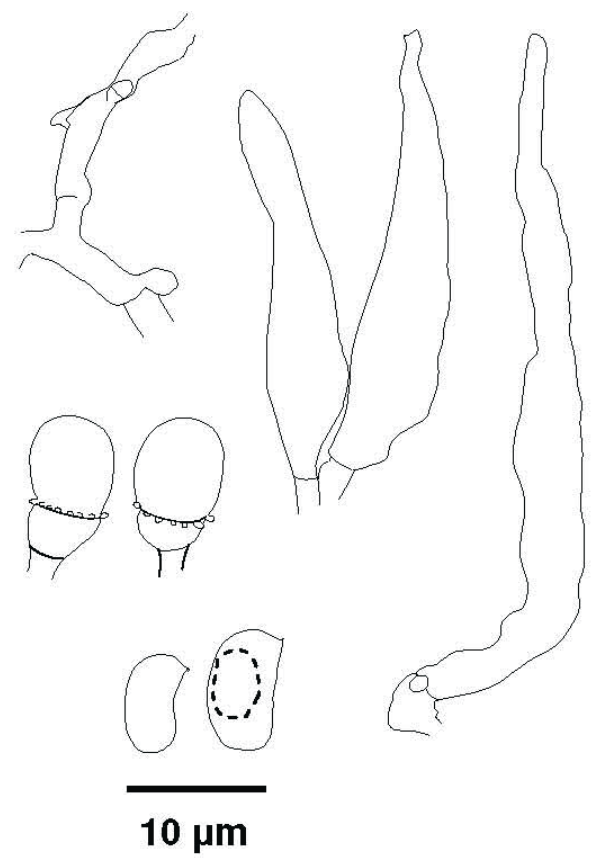

Fig. 5. Hyphoderma praetermissum.

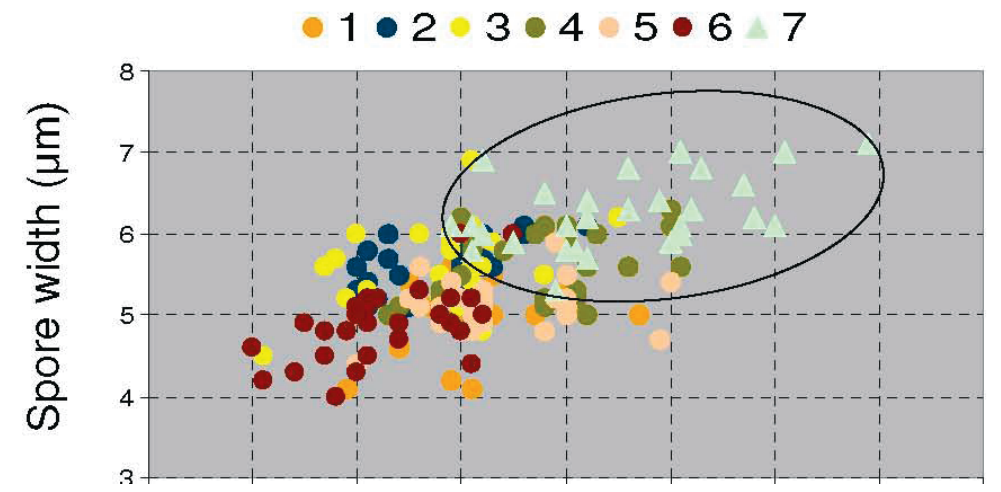

Fig. 6. A sporograph, showing the spore size of seven Hyphoderma obtusum collections. 30 spores were measured from each collection. - 1: Finland, Etelä-Häme, Korpilahti, Vaarunvuoret, Picea abies, 20.VIII.1986 Hallenberg 9515 $B$ (GB). 2: Finland, Perä-Pohjanmaa, Rovaniemi, Pisavaara, Picea abies, 28.VIII.1960 Kujala 9418 (GB). 3: Norway, Hedmark, Løten, Pinus sylvestris, 18.X.1981 Høgholen 450/81 (GB). 4: France, Var, Cineraria maritima, 16.IV.1962 Boidin 4239 (GB). 5: Poland, Nowy Sacz, Nawojowa, Rez. Scisły Łabowiec, Abies, 12.IX.1973 Hallenberg, Hjortstam \& Larsson 2339 (GB). 6: Canada, British Columbia, McLeod Lake district, Brook valley, Abies, 11.VIII.1969 Eriksson \& Eriksson 12792 (GB). 7: Norway, Svalbard, Spitsbergen, Colesbukta, Pinus, 11.VIII.2001 Kosonen 314 (TUR). 
Based on a comparison between older (Gulden \& Torkelsen 1996) and recent observations, it appears that some species have well established populations in Svalbard. In this study more than three observations were made from ten of the 26 species known to exist in Svalbard. Of these ten species, six can be considered as "common" in Svalbard (Antrodia serialis, Peniophora pithya (Pers.) J.Erikss., Veluticeps abietina (Pers. : Fr.) Hjortstam \& Tellería, Dacryobolus sudans (Alb. \& Schwein. : Fr.) Fr., Hyphoderma praetermissum and Stereum sanguinolentum (Alb. \& Schwein. : Fr.) Fr., with eight or more observations from at least two investigated areas. Some species have, all in all, been sighted only once and it is possible that some species observed before do not grow in Svalbard any more. Although the number of investigated trunks etc. was high, the true number of rare species is difficult to evaluate.

There are two ways for fungi to spread to Svalbard. Either via long-distance spore dispersal or by infected wood being transported to the islands. The species found from Svalbard are able to spread effectively by spore dispersal (Eriksson \& Ryvarden 1973, 1975, 1976; Eriksson et al. 1978, 1981; Rayner \& Boddy 1988; Hallenberg 1995). It is possible that some of the driftwood arriving by sea to Svalbard had initially been infected by fungi, either by attached spores or by mycelia. In a freshwater environment this is probably a relevant method, as proposed by Kotiranta and Mukhin (2001). As to a marine environment, it is unclear if a fungus or its propagules could survive several months in a highly saline environment as salt is highly toxic to fungi in high levels (Deacon 1997).

All the sightings were made from abandoned wooden structures originating from the first half of the $20^{\text {th }}$ century. No basidiocarps were found from driftwood. The role of driftwood as a source of new arrivals cannot be ruled out totally, as it has formerly been used as construction material. Bearing in mind the intriguing recent findings of $H$. praetermissum and the above reasoning, air dispersal seems to have played, and still plays, a major role.

Results presented in this study are based on observations made during only one season. It is well known that wood-rotting species do not produce basidiocarps every year (Hallenberg 1995). During the short growth period in Svalbard the temperature only seldom rises above ten degrees Celsius and the level of sun radiation is low (Hisdal 1998). Although many fungi continue to grow at low temperatures, and some even close to zero degrees Celsius, the metabolism - and hence growth and enzyme-activity - is very slow (Rayner \& Boddy 1988; Ritschkoff 1996; Deacon 1997). It is probable, if not very likely, that mycelia in Svalbard seldom produce basidiocarps and then only in suitable years.

Acknowledgements: Urmas Kõljalg, Heikki Kotiranta, Pekka Heinonen, and Unto Söderholm are warmly thanked for help and expertise concerning the identification of some of the specimens. Terttu Lempiäinen is warmly thanked for guidance in microscopic identification of the substrates. The curators of $\mathrm{O}$ and GB are thanked for loans of reference material. Ernest and Valerie Emmett are specially thanked for a careful scrutiny of the English.

\section{References}

Arlov, T. B. 1996: Svalbards historie. - Aschehoug \& Co, Oslo. 494 pp.

Brummit, R. K. \& Powell, C. E. 1992: Authors of plant names. - Royal Botanic Gardens, Kew. 732 pp.

Deacon, J. W. 1997: Modern mycology. - University Press, Cambridge. 298 pp.

Eriksson, J., Hjortstam, K. \& Ryvarden L. 1978: The Corticiaceae of North Europe vol. 5 - Fungiflora, Oslo. 887-1048.

Eriksson, J., Hjortstam, K. \& Ryvarden L. 1981: The Corticiaceae of North Europe vol. 6 - Fungiflora, Oslo. 1049-1276.

Eriksson, J. \& Ryvarden, L. 1973: The Corticiaceae of North Europe vol. 2. - Fungiflora, Oslo. Pp. 60-286.

Eriksson, J. \& Ryvarden, L. 1975: The Corticiaceae of North Europe vol. 3. - Fungiflora, Oslo. Pp. 287546.

Eriksson, J. \& Ryvarden, L. 1976: The Corticiaceae of North Europe vol. 4. - Fungiflora, Oslo. Pp. 547886.

Fagerstedt, K., Pellinen, K., Saranpää, P. \& Timonen, T. 1996: Mikä puu, mistä puusta. - Yliopistopaino, Helsinki. 180 pp.

Gulden, G. 1996: Fungal life on the Arctic archipelago of Svalbard. - McIlvainea 12(2): 4-20.

Gulden, G. \& Torkelsen, A.-E. 1996: Part 3. Fungi I. Basidiomycota: Agaricales, Gasteromycetales, Aphyllophorales, Exobasidiales, Dacrymycetales and Tremellales. In: A catalogue of Svalbard plants, fungi, algae and cyanobacteria (Elvebakk, A. \& Prestrud, P., eds.), pp. 173-206. - Norsk Polarinstitutt, Oslo.

Hallenberg, N. 1995: Dispersal abilites and distributional patterns in Aphyllophorales, with emphasis on corticioid fungi. - Acta Univ. Ups. Symb. Bot. Ups. 30(3): 95-100. 
Hansen, L. \& Knudsen, H. 1997: Nordic Macromycetes vol. 3. - Nordsvamp, Copenhagen. 444 pp.

Hisdal, V. 1998: Svalbard nature and history. - Norsk Polarinstitutt, Oslo. $135 \mathrm{pp}$.

Hjelle, A. 1993: Svalbards geologi. - Norsk Polarinstitutt, Oslo. 163 pp.

Jülich, W. 1984: Kleine Kryptogamenflora - die Nichtblätterpilze, Gallertpilze und Bauchpilze. - Gustav Fischer Verlag, Stuttgart. 626 pp.

Kotiranta, H. \& Mukhin, V. A. 2001: Aphyllophorales (Basidiomycetes) of Tiksi, Republic of Sakha (Yakutia), Northeast Siberia. - Karstenia 40: 65-69.

Krohn, O. 1999: Helhetlig plan for miljøtiltak i gruveområdet i Ny-Ålesund (Kings Bay). - Sysselmannens rapportserie Nr. 2/1999, Longyearbyen. 102 pp.
Niemelä, T. 2005: Käävät, puiden sienet. - Yliopistopaino, Helsinki. 320 pp.

Rayner, A. D. M. \& Boddy, L. 1988: Fungal decomposition of wood. - Wiley - Intersci. Publ., Bath. 587 pp.

Renvall, P. 1995: Community structure and dynamics of wood-rotting Basidiomycetes on decomposing conifer trunks in northern Finland. - Karstenia 35: 1-51.

Ritschkoff, A.-C. 1996: Decay mechanisms of brown-rot fungi. - VTT Publications 268, Technical Research Centre of Finland, Espoo. 67 pp. + app 38 pp.

Rønning, O. I. 1996: The flora of Svalbard. - Norsk Polarinstitutt, Oslo. 184 pp.

Torkelsen, A.-E. 1972: Gelésopper. - Universitetsforlaget, Oslo. 102 pp. 